\title{
Assessments of the Sensitivities of Cultured Human Neuroblastoma Cells to Anti-Tumour Drugs
}

\author{
BRIDGET T. HILL ${ }^{(48)}$ AND R. D. H. WHELAN \\ Laboratory of Cellular Chemotherapy, Imperial Cancer Research Fund, Lincoln's Inn Fields, London, WC2A 3PX, \\ United Kingdom
}

\section{Summary}

When logarithmically growing neuroblastoma cells were exposed in vitro for $24 \mathrm{hr}$ to a range of concentrations of various antitumour drugs and then cloned in agar to assess colony-forming ability, the dose-response curves obtained were of two types only, namely exponential-plateau or exponential. The former category, included hydroxyurea, 1,1'-propylene bispiperazine-3,5-dione (ICRF-159), vincristine and vindesine, where the plateau was reached before $1 \mathrm{log}$ cell kill, and $4^{\prime}$-demethylepipodophllotoxin thenylidine glucoside (NSC 122819) (VM-26) and 4'-demethylepipodophllotoxin-9-(4,6-oethylidine- $\beta$-D-glucopyranoside (NSC 141540) (VP-16-213), where the plateau occurred at approximately 5\% survival. Exponential survival curves were obtained with actinomycin D, Adriamycin, bleomycin, cis-dichlorodiammine platinum (II) ( cis-platinum), dibromodulcitol, 5-fluorouracil, 4'-(9-acridinylamino)methanesulfon- $m$-anisidine (NSC 249992) (mAMSA), melphalan, and peptichemio. A comparison of drug concentrations required to reduce survival in vitro by $70 \%$, with a 24 -hr drug exposure, was attempted with those concentrations achievable as plasma levels in man after conventional drug therapy. The results obtained, after many and varied assumptions, allowed the division of the drugs tested into three main groups: (1) most effective agents, including mAMSA, VM-26, and Adriamycin; (2) agents with some activity-vincristine, vindesine, VP-16-213, cis-platinum, melphalan, and peptichemio, although only when the latter three drugs were used at the higher dosage levels; (3) agents with little, if any, activity-actinomycin D, bleomycin, dibromodulcitol, 5-fluorouracil, hydroxyurea, and ICRF-159. In terms of attempting clinical correlations, available data suggest definite value in treating neuroblastoma with VM-26 and Adriamycin [from our group (1)| and also with vincristine, melphalan (high dose), peptichemio, and cis-platinum |from our group (2)|. No significant clinical activity has been reported for actinomycin D nor for bleomycin in previously treated children, and both these drugs proved negative in this model test system. Among the newer agents tested experimentally, our results suggest that although clinical evaluation of mAMSA, VP-16-213, and vindesine might be profitable, dibromodulcitol and ICRF-159 may prove inactive.

\section{Speculation}

The dismal prognosis for the majority of children with neuroblastoma serves to highlight the need for new and more effective therapies. One approach is to attempt to screen experimentally in vitro for drugs effective in this disease. Our preliminary studies, using only one cell line derived from one portion of a human tumour, have suggested, with many reservations, some correlations between in vitro and clinical data. This work is now being extended to consider other human neuroblastoma cell lines and to monitor retrospectively drug responses in vitro with clinical responses. These studies are essential before any attempts are made to extrapolate any of the in vitro results to humans.
Neuroblastoma is the most common extracranial malignant solid tumour of infancy and childhood (20). In contrast to the major advances which have occurred in the treatment of other childhood cancers, the prognosis for this disease remains poor ( 15 , 20 ). The majority are children over one year of age with metastatic disease, and despite initial responses to chemotherapy, the prognosis is dismal with 2-year survival figures of less than $10 \%$. Several agents have been reported as active in neuroblastoma, but patient numbers are small (20). Many single agents have not been tested, and few drug combinations have been adequately evaluated.

Attempts to screen experimentally specifically for agents effective in this disease have not been widely reported. Finkelstein et al. (14) described some promising preliminary studies with the C1300 murine neuroblastoma system, but the relationship between human and murine neuroblastoma is uncertain. Specific screening potentially may be a valuable approach in view of the apparent heterogenous nature of this tumour, including drug-resistant populations and a large nonproliferating pool of cells which may be less responsive to certain antitumour agents $(17,44)$. The more recent studies by Salmon et al. (37) have, however, raised great interest in in vitro drug sensitivity testing. This group has developed a human stem cell assay system which allows the response of an individual patient's tumour to a particular anticancer drug to be predicted with a very high degree of accuracy for certain tumour types, for example, ovarian cancer and melanoma. This work is now being extended by other groups, and further tumour types are being investigated $(1,8,9,16,36,43)$. We are presently attempting similar studies using biopsy material from human neuroblastomas, but this material is not readily available, quantities are limited as are the number of patients available for study, and our cloning efficiencies are low, being of the order of $0.01 \%$ (35), which of necessity restricts the number of drugs which it is possible to study. Therefore, we decided initially to work with established human neuroblastoma cell cultures. Initially, we have (1) evaluated the effectiveness of a range of anti-tumour drugs in reducing the colony-forming ability of human neuroblastoma cells in vitro and (2) attempted correlations between the effective lethal concentrations in vitro with those achievable clinically.

\section{MATERIALS AND METHODS}

\section{CHEMICALS}

The drugs used, their solvents, and their sources are listed in Table 1.

\section{CELL CULTURES}

Human neuroblastoma cells (CHPI00) were maintained in monolayer culture in Roswell Park Memorial Institute 1640 medium (Gibco Bio-Cult, Renfrewshire, Scotland) supplemented with $10 \%$ fetal calf serum (Flow Laboratories, Irvine, Scotland) at $37^{\circ} \mathrm{C}$ in a humidified $10 \% \mathrm{CO}_{2}-90 \%$ air atmosphere. This line of 
Table 1. The drugs used and their sources ${ }^{1}$

\begin{tabular}{|c|c|}
\hline Drugs & Source \\
\hline Actinomycin D & $\begin{array}{l}\text { Merck, Sharp and Dohme Ltd., Hoddesdon, Herts., } \\
\text { United Kingdom }\end{array}$ \\
\hline Adriamycin & $\begin{array}{l}\text { Gift from Farmitalia Carlo Erba Ltd., Barnet, } \\
\text { Herts., United Kingdom }\end{array}$ \\
\hline $\mathrm{mAMSA}^{2}$ & Gift from Warner-Lambert Co., Morris Plains, NJ \\
\hline Bleomycin & $\begin{array}{l}\text { Gift from Lundbeck Ltd., Luton, Beds., United } \\
\text { Kingdom }\end{array}$ \\
\hline Cis-Platinum & $\begin{array}{l}\text { The Boehringer Corporation (London) Ltd., United } \\
\text { Kingdom }\end{array}$ \\
\hline Dibromodulcitol & $\begin{array}{l}\text { The Developmental Therapeutics Program, Chemo- } \\
\text { therapy, N.C.I., Bethesda, MD }\end{array}$ \\
\hline 5-Fluorouracil & $\begin{array}{l}\text { Roche Products Ltd., Welwyn Garden City, Herts., } \\
\text { United Kingdom }\end{array}$ \\
\hline Hydroxyurea & $\begin{array}{l}\text { Gift from E. R. Squibb \& Sons Ltd., Wirral, Mer- } \\
\text { seyside, United Kingdom }\end{array}$ \\
\hline ICRF-159 & $\begin{array}{l}\text { Gift from Dr. A. H. Creighton, The Imperial Cancer } \\
\text { Research Fund Laboratories, London, United } \\
\text { Kingdom }\end{array}$ \\
\hline Melphalan & $\begin{array}{l}\text { The Wellcome Foundation Ltd., London, United } \\
\text { Kingdom }\end{array}$ \\
\hline Peptichemio & $\begin{array}{l}\text { Instituto Sieroterapica Milanese S. Belfanti, Milan, } \\
\text { Italy }\end{array}$ \\
\hline $\begin{array}{l}\text { Vincristine and } \\
\text { Vindesine }\end{array}$ & $\begin{array}{l}\text { Gifts from Eli Lilly \& Co., Ltd., Basingstoke, Hants., } \\
\text { United Kingdom }\end{array}$ \\
\hline VM-26 & Sandoz AG, Basel, Switzerland. \\
\hline VP-16-213 & Sandoz AG, Basel, Switzerland. \\
\hline
\end{tabular}

All the drugs were dissolved in phosphate-buffered saline or Roswell Park Memorial Institute 1640 tissue culture medium with the exception of (1) dibromodulcitol, which was solubilized in a minimum quantity of dimethyl sulfoxide and then diluted to less than $0.1 \%$ in Roswell Park Memorial Institute 1640 medium before adding to cultures; (2) melphalan, which was solubilized in a minimum quantity of $4.5 \%$ (w/v) ethanolic $\mathrm{HCl}$ and then diluted at least $\times 50$ in Roswell Park Memorial Institute 1640 medium before addition to cultures; and (3) 4'-(9-acridinylamino)methanesulfon-m-anisidide (NSC 249992), for which the diluent was $0.0353 \mathrm{M}_{\text {L-lactic acid }}$

${ }^{2}$ The abbreviations used are: mAMSA, 4'-(9-acridinylamino)methanesulfon- $m$-anisidie (NSC 249992); cis-platinum, cis-dichlorodiammine platinum(II); ICRF-159, 1,1'-propylene bispiperazine-3,5-dione; VM-26, 4'-demethylepipodophllotoxin thenylidine glucoside (NSC 122819); VP-16-213, 4'-demethylepipodophllotoxin-9-(4,6-oethylidine- $\beta$ D-glucopyranoside) (NSC 141540).

cells, which was obtained from Dr. H. R. Schlesinger, The Children's Hospital, Philadelphia, PA, has been maintained in our laboratory for the last 12 months with weekly passaging and kept in liquid-nitrogen storage. Since the initial characterization of this cell line (38), the later passage cells used in these present experiments differ in two respects: (1) under our culture conditions the population doubling time is approximately $22 \mathrm{hr}$ and (2) treatment with trypsin and careful mechanical aspiration results in a uniform single cell suspension.

Cells were routinely monitored for the presence of Mycoplasma by testing for growth on nutrient agar and by direct microscopy of the aceto-orcein stained monolayers. Only data obtained using Mycoplasma-free cultures is presented. Metaphase preparations of these neuroblastoma cells provided evidence of their human chromosome pattern and the absence of cells of murine origin.

\section{AGAR COLONY-FORMING ASSAYS}

The colony-forming assays were performed as follows: initial dose-response curves of the cells, growing as monolayers, to a 24 hr drug exposure were obtained by cell counts on 5 successive days. From these data, for each drug tested, the appropriate concentration ranges were selected, and the approximate log cell kill produced was calculated. This enabled the number of cells plated in the viability assays to be varied so that approximately 100 colonies per tube were obtained for counting. In these assays, the cells used were in logarithmic growth when exposed to the selected range of drug concentrations for $24 \mathrm{hr}$ only, after which the medium was removed. The CHPIO0 cells were then washed with serum-free medium, trypsinized $(0.25 \%$ trypsin as Tryptar from Armour Pharmaceuticals Co. Ltd., Eastbourne, United Kingdom) and resuspended in fresh Roswell Park Memorial Institute medium containing $10 \%$ fetal calf serum at $37^{\circ} \mathrm{C}$. The appropriate number of cells were then added in $1 \mathrm{ml}$ to $15 \mathrm{ml}$ plastic tubes (Sterilin; Teddington, Middlesex, United Kingdom), and $5 \mathrm{ml}$ of an agarose-containing mixture prepared in medium plus $10 \%$ fetal calf serum were added. The final agarose concentration was $0.17 \%$. The cells were then incubated at $37^{\circ} \mathrm{C}$ in an atmosphere of $10 \%$ $\mathrm{CO}_{2}-90 \%$ air for approximately $3 \mathrm{wk}$ before colony counting. The cloning efficiency of CHP100 cells was approximately 25 to $40 \%$.

Treated cultures are expressed as a percentage of the control (nontreated or solvent-treated) cultures, which were given the value of $100 \%$. The mean \pm S.E. of colony counts from replicate cultures, with each experiment repeated twice, were calculated, and survival curves were plotted on a semilogarithmic scale with the percentage surviving fraction against drug concentration.

\section{RESULTS}

The dose-response curves obtained following a 24-hr drug exposure are shown in Figures 1 and 2. The drugs selected can be divided into two main groups, based on the shape of the dose-
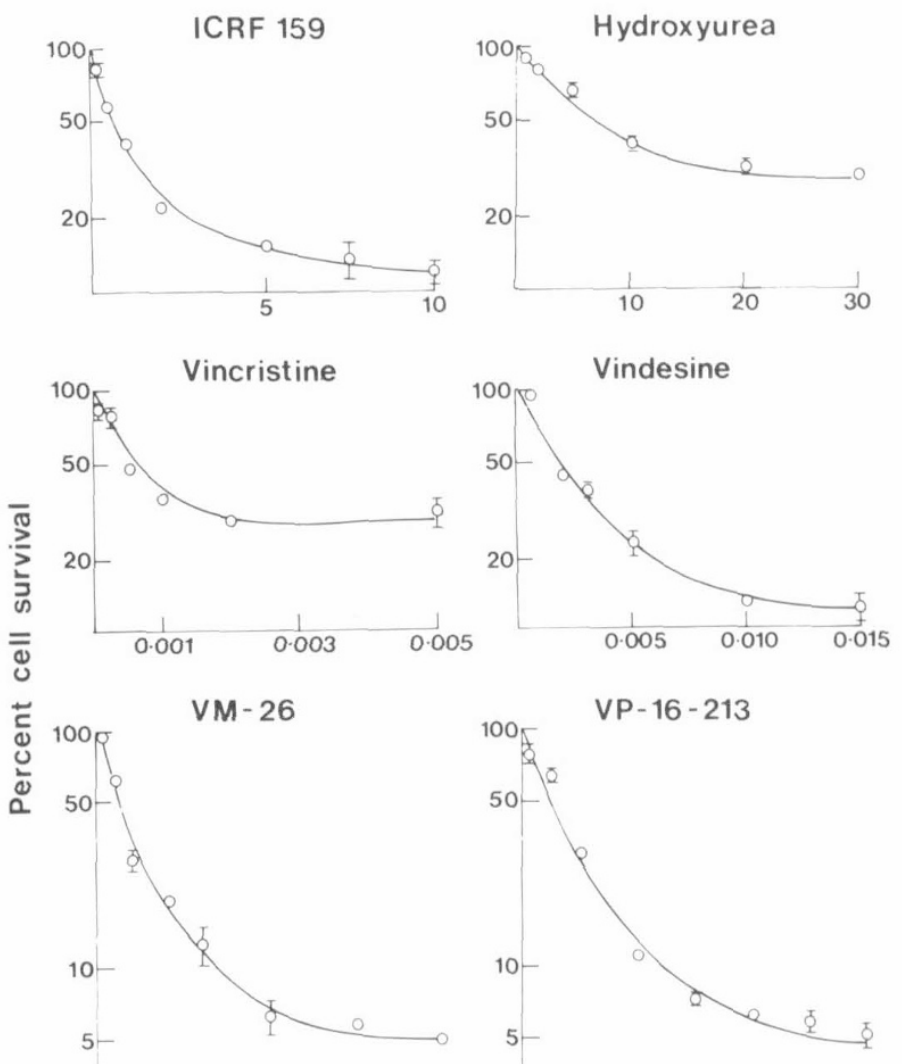

5

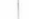

0.05 $0 \cdot 10$

$\mu \mathrm{g}$ per $\mathrm{ml}$

Fig. 1. The effects of a 24-hr exposure to increasing drug concentrations on the colony-forming ability of human neuroblastoma cells in culture. Points, mean of four estimations; the experiments have been repeated at least twice. Only standard errors in excess of $5 \%$ have been included as error bars on the figures. 

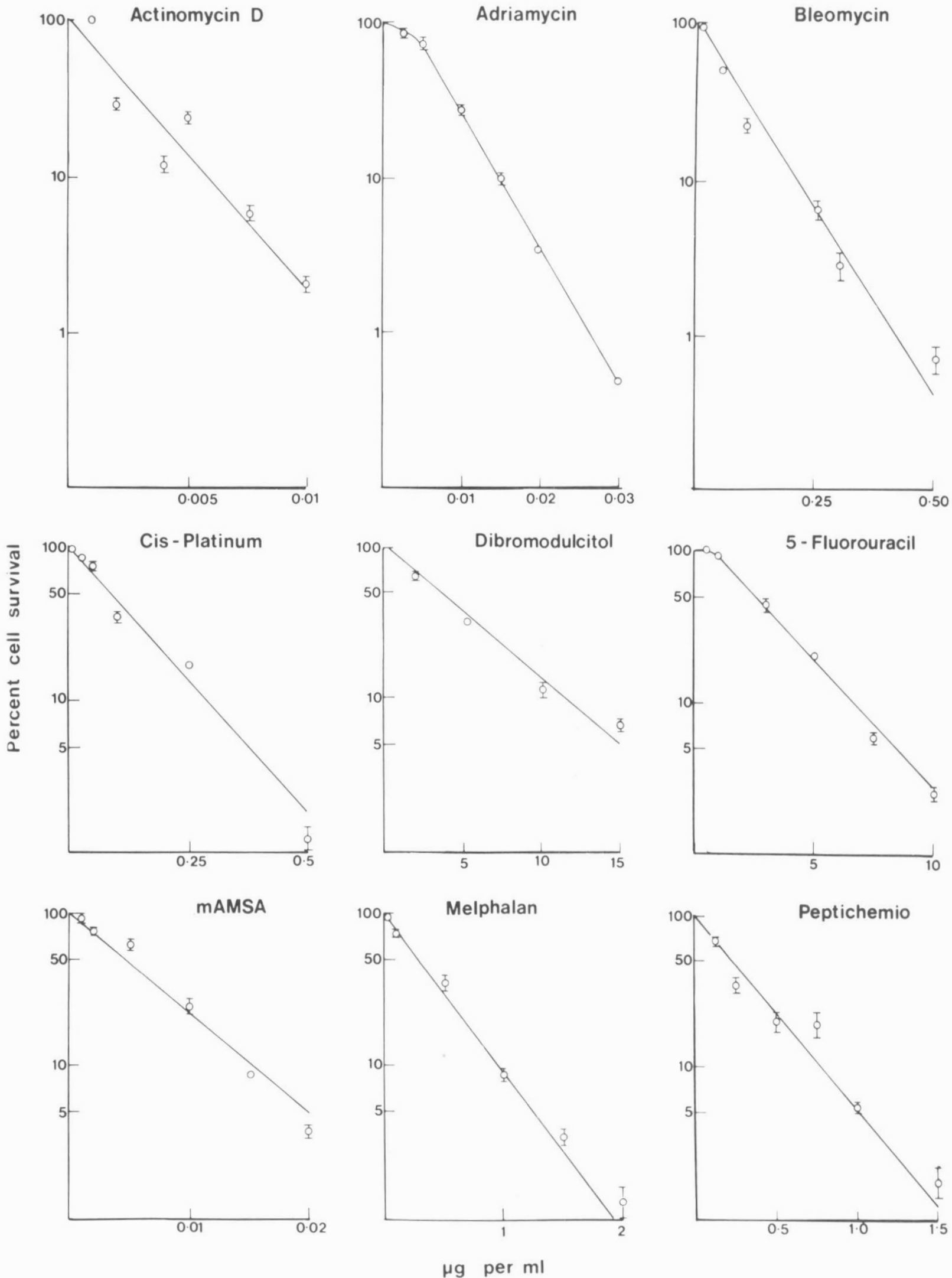

$\mu \mathrm{g}$ per $\mathrm{ml}$

Fig. 2. The effects of a 24-hr exposure to increasing drug concentrations on the colony-forming ability of human neuroblastoma cells in culture. Points, mean of four estimations; the experiments have been repeated at least twice. Only standard errors in excess of $5 \%$ have been included as error bars on the figures.

response curve obtained under these conditions, namely exponential-plateau or exponential. In the former group, the plateau region is reached before a $1 \mathrm{log}$ cell kill is achieved for all the drugs tested with the exception of the podophyllotoxin derivatives, where the plateau occurs at approximately $5 \%$. This suggests a limited cell killing effectiveness with this particular group of agents for a fixed time of exposure. Figure 1 contains the results obtained with these drugs where the survival curves after a 24-hr drug exposure, plateau irrespective of increasing drug concentrations. It should be noted that approximately three times more vindesine is required 
Table 2. A comparison of in vitro drug concentrations required to reduce survival by $70 \%$ with those plasma levels achievable clinically

\begin{tabular}{|c|c|c|c|c|}
\hline Drugs & $\begin{array}{l}\text { Clinical doses } \\
\left(\mathrm{mg} / \mathrm{m}^{2}\right)^{1}\end{array}$ & $\begin{array}{c}\text { Maximum peak } \\
\text { plasma levels at } \\
\text { zero time } \\
(\mu \mathrm{g} / \mathrm{ml})^{2}\end{array}$ & $\begin{array}{l}\text { Concentrations } \\
\text { in vitro for } \\
70 \% \text { growth } \\
\text { inhibition } \\
(\mu \mathrm{g} / \mathrm{ml})^{4}\end{array}$ & $\begin{array}{c}N \\
\text { factor } \\
\left(\times 10^{3}\right)^{6}\end{array}$ \\
\hline Actinomycin D & $0.5-0.75$ & $0.4-0.6^{3}$ & 0.0035 & $0.12-0.17$ \\
\hline Adriamycin & $30-50$ & $10-40$ & 0.0096 & $1.1-4.2$ \\
\hline mAMSA & $50-120$ & $40-100$ & 0.008 & $5-12.5$ \\
\hline Bleomycin & $10-25$ & $8-20$ & 0.110 & $0.07-0.18$ \\
\hline Cis-Platinum & $20-100$ & $15-80$ & 0.145 & $0.11-0.55$ \\
\hline Dibromodulcitol & 400 & 320 & 6.1 & 0.05 \\
\hline 5-Fluorouracil & $250-500$ & $200-400^{3}$ & 3.9 & $0.05-0.10$ \\
\hline Hydroxyurea & 3800 & $3000^{3}$ & 16.8 & 0.18 \\
\hline ICRF-159 & $1000-11000$ & $5-20^{3}$ & 1.35 & $0.004-0.015$ \\
\hline Melphalan & $30 / 140$ & $25 / 120$ & 0.50 & $0.05-0.24$ \\
\hline Peptichemio & $50-150$ & $40-120$ & 0.41 & $0.10-0.30$ \\
\hline Vincristine & $1-2$ & $0.8-1.5$ & 0.0016 & $0.50-0.94$ \\
\hline Vindesine & $3-5$ & $2.5-4.2$ & 0.0037 & $0.68-1.14$ \\
\hline VM 26 & $100-150$ & $80-120$ & 0.012 & $6.6-10$ \\
\hline VP-16-213 & $50-100$ & $40-80$ & 0.08 & $0.50-1.0$ \\
\hline
\end{tabular}

'Standard clinical ranges given as a single dose.

${ }^{2}$ Calculated by assuming maximum distribution in $1.2 \mathrm{~L}$ plasma at 'zero' time, except where specific published data are available $(18,46)$.

${ }^{4}$ Established from data presented in Figures 1 and 2.

"The abbreviations used are: mAMSA, 4'-(9-acridinylamino)methanesulfon-m-anisidide (NSC 249992); cis-platinum, cis-dichlorodiammine platinum(II); ICRF-59, I, I'-propylene bispiperazine-3,5-dione; VM-26, 4'-demethylepipodophllotoxin thenylidine glucoside (NSC 122819); VP-16-213, 4'demethylepipodophllotoxin-9-(4,6-oethylidine- $\beta$-D-glucopyranoside) (NSC 141540).

${ }^{6}$ Calculated by dividing the plasma levels by the in vitro concentrations.

than vincristine to achieve an equivalent cell kill. Because the clinical dosage of vindesine is conventionally approximately three times greater than that for vincristine, on a $\mathrm{mg} / \mathrm{m}^{2}$ basis, this suggests equal effectiveness for these two Vinca alkaloids in this model system. However, approximately six times more $4^{\prime}$-demethylepipodophllotoxin-9-(4,6-oethylidine- $\beta$-D-glucopyranoside) (NSC 141540) (VP-16-213) is required than $4^{\prime}$-demethylepipodophllotoxin thenylidine glucoside (NSC 122819) (VM-26) to achieve an equivalent cell kill, suggesting superiority for VM-26, especially because the clinical dosage of VM-26 is conventionally approximately twice that for VP-16-213.

Figure 2 illustrates the results obtained with drugs where increasing drug concentrations result in increasing cell kill. In this figure, it can be seen that similar concentrations of peptichemio and melphalan achieve comparable extents of cell kill. Because $100 \mathrm{mg}$ of peptichemio are considered to contain only $40 \mathrm{mg}$ equivalents of melphalan, this observation suggests superiority for peptichemio in this test system.

In an attempt to establish whether the sensitivity of these neuroblastoma cells in culture to various anti-tumour agents could provide any information as to the clinical usefulness of certain specific drugs, a comparison of drug concentrations required to reduce survival by $70 \%$ with a $24-\mathrm{hr}$ exposure was attempted with those concentrations achievable as peak plasma levels in man after conventional drug therapy. This figure of $70 \%$ reduction is used by Alberts et al. (1) and Salmon et al. $(36,37)$ to predict sensitivity in their human tumour stem cell assays. Our results are listed in Table 2. The maximum peak plasma levels have been calculated using standard single clinical drug doses and assuming maximum distribution in 1.2 litres of plasma at "zero time," except where specific published data are already available $(18,46)$. The "N" factor in the last column has been obtained by dividing the suggested plasma levels achieved by the in vitro inhibitory drug concentration. Therefore, after these many and varied assumptions, this factor provides a suggested degree of efficacy for each drug tested. Using these data, it is possible to separate the drugs into three groups as shown in Table 3, namely the most effective agents, those with intermediate effectiveness, and those with low " $N$ " values. A similar grouping of "effectiveness" is obtained if the clinical drug levels are estimated according to the procedure recommended by Limburg and Heckmann (21) who assumed the total drug dosage was distributed in plasma only.
Table 3. Assessment of effectiveness of anti-tunour drugs against neuroblastoma cultures

Most effective agents tested ( $\mathrm{N}$ factor $>1.0$ )

mAMSA $^{\prime}$

VM-26

Adriamycin

Agents with some effects ( $\mathrm{N}$ factor 0.2 to 1 )

$\left.\begin{array}{l}\text { Vincristine } \\ \text { Vindesine } \\ \text { VP-16-213 } \\ \text { cis-Platinum } \\ \text { Melphalan } \\ \text { Peptichemio }\end{array}\right\}$ higher doses

Agents with little effect $(\mathrm{N}$ factor $<0.2)$
Actinomycin D
Bleomycin
Dibromodulcitol
5-Fluorouracil
Hydroxyurea
ICRF-159
cis-Platinum
$\left.\begin{array}{l}\text { Melphalan } \\ \text { Peptichemio }\end{array}\right\}$ low doses

The abbreviations used are: mAMSA, 4'-(9-acridinylamino)methanesulfon- $m$-anisidide (NSC 249992); VM-26, 4'-demethylepipodophllotoxin thenylidine glucoside (NSC 122819); VP-16-213, 4'-demethylepipodophllotoxin-9-(4,6-oethylidine- $\beta$-D-glucopyranoside) (NSC 141540); cis-platinum, cis-dichlorodiammine platinum(II); ICRF-159, I, I' propylene bispiperazine-3,5-dione.

\section{DISCUSSION}

The effects of drugs on cell survival can be reliably estimated by colony-forming assays. These data are highly reproducible from experiment to experiment, and we obtained no evidence of any alterations in drug sensitivities after maintaining the cells in culture for one year nor after their recovery from storage in liquid 
Table 4. Drugs tested in the clinic for evidence of activity as single agents against neuroblastoma

\begin{tabular}{|c|c|c|c|c|c|}
\hline Drugs & Doses & Results & & & References \\
\hline \multirow[t]{2}{*}{ Adriamycin } & $\begin{array}{l}60 \mathrm{mg} / \mathrm{m}^{2} \text { single dose or split over } 2 \text { or } 3 \\
\text { consecutive days }\end{array}$ & Overall response ${ }^{1}$ & $44 / 117$ & $(38)^{2}$ & 40 \\
\hline & Not stated & Overall response & $21 / 71$ & $(30)$ & 6 \\
\hline \multirow[t]{3}{*}{ cis-Platinum } & $15-20 \mathrm{mg} / \mathrm{m}^{2}$ daily for 5 days & RT-Overall response & $6 / 22$ & (27) & 26 \\
\hline & $100 \mathrm{mg} / \mathrm{m}^{2}$ & UT-Overall response & $2 / 3$ & $(67)$ & 10 \\
\hline & $100 \mathrm{mg} / \mathrm{m}^{2}$ & RT-Overall response & $5 / 10$ & $(50)$ & 30 \\
\hline \multirow[t]{4}{*}{ Melphalan } & $0.2 \mathrm{mg} / \mathrm{kg}$ daily for 28 days (oral) & RT-Overall response & $0 / 8$ & $(0)$ & 13 \\
\hline & $0.2 \mathrm{mg} / \mathrm{kg}$ daily for 5 days (IV) & RT-Overall response & $0 / 5$ & $(0)$ & 13 \\
\hline & $30 \mathrm{mg} / \mathrm{m}^{2}$ & "low dose"-Overall response & $1 / 4$ & $(25)$ & 25 \\
\hline & $140 \mathrm{mg} / \mathrm{m}^{2}$ & "high dose"-Overall response & $5 / 7$ & (71) $[\mathrm{ICR}]$ & 25 \\
\hline \multirow[t]{4}{*}{ Peptichemio } & $1-1.5 \mathrm{mg} / \mathrm{kg}$ daily for $5-6$ days & UT-Overall response & $8 / 12$ & (67) $[2 \mathrm{CR}]$ & 11 \\
\hline & $1-1.5 \mathrm{mg} / \mathrm{kg}$ daily for $3-5$ days & UT-Overall response & $5 / 9$ & (56) $[\mathrm{ICR}]$ & 27 \\
\hline & $1-1.5 \mathrm{mg} / \mathrm{kg}$ daily for $5-6$ days & RT-Overall response & $1 / 4$ & $(25)$ & 11 \\
\hline & $1-1.5 \mathrm{mg} / \mathrm{kg}$ daily for $3-5$ days & RT-Overall response & $3 / 4$ & (75) $[3 \mathrm{CR}]$ & 27 \\
\hline \multirow[t]{3}{*}{ Vincristine } & $0.02 \mathrm{mg} / \mathrm{kg}$ daily for 5 days & Overall response & $3 / 13$ & (23) $[\mathrm{ICR}]$ & 45 \\
\hline & $1-2.5 \mathrm{mg} / \mathrm{m}^{2} / \mathrm{wk}$ & Overall response & $28 / 71$ & $(40)$ & 22 \\
\hline & $2.5 \mathrm{mg} / \mathrm{m}^{2} / \mathrm{wk}$ & Overall response & $18 / 33$ & (55) $[4 \mathrm{CR}]$ & 39 \\
\hline \multirow[t]{2}{*}{ VM-26 } & $130-180 \mathrm{mg} / \mathrm{m}^{2} / \mathrm{wk}$ & RT-Overall response & $10 / 31$ & (32) $[\mathrm{ICR}]$ & 5 \\
\hline & $100 \mathrm{mg} / \mathrm{m}^{2}$ twice weekly & RT-Overall response & $3 / 7$ & $(43)$ & 33 \\
\hline VP-16-213 & $100-150 \mathrm{mg} / \mathrm{m}^{2}$ daily for 5 days & RT-Overall response & $1 / 5$ & (20) & 4 \\
\hline \multirow[t]{2}{*}{ Actinomycin D } & "Conventional doses" & No significant activity & & & 12 \\
\hline & & & & & 41 \\
\hline
\end{tabular}

'Overall response, objective responses; cis-platinum, cis-dichlorodiammine platinum(II); RT, previously treated patients with progressive metastic disease; UT, previously untreated patients; CR, complete response; VM-26, 4'-demethylepipodophllotoxin thenylide glucoside (NSC 122819); VP-16213, 4'-demethyle.

${ }^{2}$ Numbers in parentheses, percent.

nitrogen. Viability assays using colony formation in semisolid agar tend not only to be very time consuming to set up but also do not provide rapid results because at least 14 days are required for colony growth before assessment. However, this procedure is considered the best available technique for accurately determining cell kill $(3,34)$, providing a far more reliable estimation of reproductive ability than simpler methods based purely on total cell counts or the exclusion of vital dyes such as trypan blue.

The patterns of cell survival after $24 \mathrm{hr}$ exposure to the various drugs tested confirm the division of drugs as Class II and Class III agents originally proposed by W. R. Bruce et al. (7) and extended subsequently by other authors $(19,23,31,32,42)$ when they suggested the Kinetic Classification of Anti-tumour Drugs. A knowledge of this classification already has proven value in designing safer clinical chemotherapy protocols $(19,28,29)$. The administration of drug combinations over approximately $24 \mathrm{hr}$ rather than several days has been shown to reduce the toxicity without compromising antitumour effectiveness. When designing such combinations, it has been found that the toxicity of Class II agents to normal stem cells (e.g., bone marrow) is not dosedependent. Class II drugs therefore may be added to combinations without reducing their dose, provided the total treatment time is approximately $24 \mathrm{hr}$. Combinations of Class III drugs will be additively toxic to normal bone marrow, and therefore, doses should be reduced proportionately (19). These present data therefore provide evidence that this Kinetic Classification can also be derived from studies using human tumour colony-forming cells in vitro. This simple model system may therefore be more convenient than the original spleen colony assay procedure, especially for testing new agents and determining whether they belong in Class II or Class III.

Finally, we have tried to correlate these laboratory data with available clinical information (see Table 4), as to the value of these drugs as single agents in the treatment of neuroblastoma. Information is not available on all the drugs we have tested experimentally, but Table 4 contains the information for those that have been evaluated clinically in this disease. These results suggest that the most effective agents in the clinic include cisdichlorodiammine platinum (II), VM-26, Adriamycin, and peptichemio and melphalan at higher doses, with some value also claimed for vincristine. Our laboratory data (see Table 3) also selects these agents as effective in vitro together with $4^{\prime}$-(9-acridi- nylamino)methanesulfon- $m$-anisidine (NSC 249992), VP-16-213, and vindesine, drugs which have not yet received clinical evaluation against this disease. In addition, actinomycin D which has been evaluated as not effective clinically also has a low $\mathrm{N}$ factor from in vitro studies, as does bleomycin, which was shown clinically to be of no benefit in combinatioin with vincristine in previously treated children with metastatic disease (2).

Attempts to relate in vitro drug sensitivity to clinical responses are complicated by the lack of adequate pharmacologic data in man. There is a definite requirement for detailed knowledge, not only of plasma drug levels but more particularly of tumour drug levels if such correlations are to be meaningful. It is also essential to remember that the experimental studies presented involved the use of only one line of human neuroblastoma cells derived from a single clinical specimen. These particular cells therefore may be in no way representative, either of the total tumour from which the line was derived or indeed from any other tumour from other patients, as regards response to chemotherapy. However, with these many reservations and bearing in mind the simplifications and assumptions which have been made in this paper, it would appear that some correlations between this initial in vitro work and clinical studies have been noted. Our results suggest that a further evaluation of $4^{\prime}$-(9-acridinylamino)methanesulfon- $m$-anisidine (NSC 249992), VP-16-213, and vindesine might be worthwhile. However, 1, 1' -propylene bispiperazine-3,5-dione and dibromodulcitol proved ineffective experimentally in this model system. Unfortunately, we were not able to study the effects of cyclophosphamide, a drug widely used with beneficial results in this disease $(20,24)$ because the drug requires metabolic activation, and it is unsuitable therefore for in vitro studies. A similar problem exists for dimethyltriazeno-imidazole-carboxamide for which some activity has also been reported (20).

However, we are encouraged by these preliminary results and feel that further investigations are warranted in other human neuroblastoma cell lines to determine how reproducible and significant these preliminary data are and are hopeful of using human tumour biopsy material directly to check the drug sensitivities of individual patient's tumours.

\section{REFERENCES AND NOTES}

1. Alberts, D. S., Salmon, S. E., Chen, H. S. G., Surwit, E. A., Soehnlen. B., Young. L., and Moon, T. E.: In vitro clonogenic assay for predicting response of 
ovarian cancer to chemotherapy. Lancet. 2: 340 (1980)

2. Bernstein. I. D.. Evans, A. E.. Finklestein. J., Klemperer, M.. Hittle. R.. Leikin. S., and Hammond. G. D.: Phase II study of the failure of vincristine and bleomycin for previously treated children with metastatic neuroblastoma: a report from the Children's Cancer Study Group. Cancer Treat. Rep.. 62: 1201 (1978)

3. Bhuyan. B. K.. Loughman. B. E.. Fraser, T. J.. and Day, K. J.: Comparison of different methods of determining cell viability after exposure to cytotoxic compounds. Exp. Cell Res.. 97: 275 (1976)

4. Bleyer. W. A.. Chard. R. L., Krivit, W.. and Hammond, D.: Epipodophyllotoxin therapy of childhood neoplasia: a comparative Phase II analysis of VM26 and VP-16-213. Proc. Am. Assoc. Cancer Res.. 19: 373 (1978).

5. Bleyer. W. A.. Krivit. W.. Chard. R. L.. and Hammond, D.: Phase II study of VM-26 in acute leukaemia, neuroblastoma, and other refractory childhood malignancies: a report from the Children's Cancer Study Group. Cancer Treat. Rep.. 63: 977 (1979)

6. Blum. R. H.: An overview of studies with Adriamycin (NSC-123127) in the United States. Cancer Chemother. Rep., 6 (Part III): 247 (1975).

7. Bruce. W. R., Meeker, B. E., and Valeriote, F. A.: Comparison of the sensitivity of normal hematopoietic and transplanted lymphoma colony-forming cells to chemotherapeutic agents administered in vivo. J. Natl. Cancer Inst.. 37: 233 (1966)

8. Buick. R. N.. Stanisic. T. H., Fry, S. E.. Salmon, S. E., Trent. J. M., and Krasovich. P.: Development of an agar-methyl cellulose clonogenic assay for cells in transitional cell carcinoma of the human bladder. Cancer Res.. 39: 5051 (1979).

9. Carney, D. N.. Gazdar. A. F., and Minna. J. D.: Positive correlation between histological tumour involvement and generation of tumour cell colonies in agarose in specimens taken directly from patients with small-cell carcinoma of the lung. Cancer Res., 40: 1820 (1980).

10. Civik. N., and Hicsonmez, G.: Personal communication. Reported at the Societe International Oncologie Paediatric meeting (1977)

11. DeBernardi. B.. Comelli. A.. Cozzutto, C.. Lamedica, G., Mori, P. G., and Massimo, L.: Peptichemio in advanced neuroblastoma. Cancer Treat. Rep., 62: 811 (1978).

12. Evans, C. E.: Treatment of neuroblastoma. Cancer (Phila.), 30: 1595 (1972).

13. Fernbach. D. J.. Haddy, T. B., Holcomb, T. M., Stuckey, W. J.. Sullivan, M. P.. and Watkins. W. L.: L-Sarcolysin (NSC-8806) therapy for children with metastatic neuroblastoma. Cancer Chemother. Rep., 52: 293 (1968).

14. Finkelstein. J. Z.. Tittle. K.. Meshnik, R., and Weiner, J.: Murine neuroblastoma: Further evaluation of the $\mathrm{C} 1300$ model with single antitumour agents. Cancer Chemother. Rep., 59: 975 (1975).

15. Green, A. A.. Hustu, H. O.. Palmer. R., and Pinkel, D.: Total-body sequential segmental irradiation and combination chemotherapy for children with disseminated neuroblastoma. Cancer (Phila.), 38: 2250 (1976).

16. Hamburger, A. W., and Salmon, S. E.: Primary bioassay of human tumour stem cells. Science (Wash. D.C.), 197: 461 (1977).

17. Hayes, F. A. Green. A. A.. and Mauer. A. M.: Correlation of cell kinetic and clinical response to chemotherapy in disseminated neuroblastoma. Cancer Res.. 37: 3766 (1977).

18. Hill, B. T. The effectiveness of clinically useful antitumour agents as inhibitors of RNA polymerases. Cancer Biochem. Biophys., 2: 45 (1977).

19. Hill, B. T.: Cancer chemotherapy, the relevance of certain concepts of cell cycle kinetics. Biochim. Biophys. Acta. 516: 389 (1978).

20. Jaffe, N.: Neuroblastoma: review of the literature and an examination of factors contributing to its enigmatic character. Cancer Treat. Rev.. 3: 61 (1976).

21. Limburg. H., and Heckmann. U.: Chemotherapy and the treatment of advanced pelvic malignant disease with special reference to ovarian cancer. J. Obstet. Gynaecol. Br. Commonw., 75: 1246 (1968).

22. Livingston. R. B.. and Carter, S. K.: Single Agents in Cancer Chemotherapy. pp. 310-311 (IFI/Plenum Press, New York, 1970)

23. Marsh. J. C.: The effects of cancer chemotherapeutic agents on normal hematopoietic precursor cells: a review. Cancer Res., 36: 1853 (1976).

24. Maurer, H. M.: Current concepts in cancer: solid tumours in children. N. Engl. J. Med., 299: 1345 (1978)

25. McElwain. T. J., and Pritchard, J.: Unpublished observations.

26. Nitsche, R., Starling, K., Vats, T., and Bryan, H.: cis-Diamminedichloroplatinum (NSC-119875) in childhood malignancies. A South West Oncology Study Group. Med. Pediatr. Oncol., 4: 127 (1978).

27. Otten, J., and Maurus, R.: Clinical trial of peptichemio in solid tumours of childhood. Cancer Treat. Rep., 62: 1015 (1978).
28. Price, L. A.. and Goldie. J. H.: Multiple drug treatment of disseminated solid tumours. Br. Med. J., 4: 336 (1971).

29 Price, L. A. Hill, B. T. Calvert, A. H. Dalley, V. M.. Levene, A.. Busby, E. R. Schacter. M.. and Shaw. H. J.: Improved results in combination chemotherapy of head and neck cancer using a kinetically-based approach: a randomised study with and without Adriamycin. Oncology, 35: 26 (1978).

30. Pritchard. J., and Malpas, J. S.: Unpublished observations.

31. Van Putten. L. M.: Are cell kinetic data relevant for the design of tumour chemotherapy schedules? Cell Tissue Kinet., 7: 493 (1974).

32. Van Putten, L. M., Lelieveld, P.., and Kram-Idsenga, L. K. J.: Cell-cycle specificy and therapeutic effectiveness of cytostatic agents. Cancer Chemother. Rep., 56: 691 (1972).

33. Rivera, G., Green, A., Hayes, A., Avery, T., and Pratt, C.: Epipodophyllotoxin VM-26 in the treatment of childhood neuroblastoma. Cancer Treat. Rep., 61: 1243 (1977).

34. Roper, P.. and Drewinko, B.: Comparison of in vitro methods to determine druginduced cell lethality. Cancer Res., 36: 2182 (1976).

35. Rupniak. H. T., and Hill. B. T.: The poor cloning ability in agar of human tumour cells from biopsies of primary tumours. Cell Biol. Int. Rep., 4: 479 (1980).

36. Salmon, S. E.. Buick. R. N.. Soehnlen. B., Trent, J., Durie, B., Alberts, D., and Meyskens, F.: Human tumour cloning in vitro: insights on biology, kinetics and prediction of response to treatment. Proc. of Xth Meeting of the European Study Group for Cell Proliferation. Cell and Tissue Kinet., 13: 224 (1980).

37. Salmon, S. E., Hamburger, A. W., Soehnlen, B., Durie, B. G. M., Alberts. D. S.. and Moon, T. E.: Quantitation of differential sensitivity of human-tumour stem cells to anti-cancer drugs. N. Engl. J. Med., 298: 3121 (1978).

38. Schlesinger, H. R., Gerson, J. M., Moorhead, P. S., Maguire, H., and Hummeler, $\mathrm{K}$.: Establishment and characterization of human neuroblastoma cell lines. Cancer Res.. 36: 3094 (1978).

39. Selawry, O. S., Holland, J. F., and Wolman, I. J.: Effect of vincristine on malignant solid tumours in children. Cancer Chemother. Rep., 52: 497 (1968).

40. Tan. C. Rosen, G., Ghavimi, F.. Haghbin. M., Helson. L.. Wollner. N.. and Murphy, M. L.: Adriamycin (NSC-123127) in pediatric malignancies. Cancer Chemother. Rep., 6 (Part III): 259 (1975).

41. Truman, J. T.: Chemotherapy of Neuroblastoma. In: C. Pochedly: Neuroblastoma. Chap. 12, pp. 263-271 (Edward Arnold, 1977).

42. Valeriote, F. A., and Tolen, S. J.: Survival of hematopoietic and lympohoma colony-forming cells in vivo following the administration of a variety of alkylating agents. Cancer Res., 32: 370 (1972).

43. Von Hoff, D. D., Rozencweig. M., and Muggia. F. M.: The evaluation of cytotoxic drugs. Cancer Treat. Rev., 6: I (1979).

44. Wagner, H. P., and Kaser, H.: Cell proliferation in neuroblastoma. Eur. J. Cancer, 6: 369 (1970).

45. Windmiller, J., Berry, D. H., Haddy, T. B., Vietti, T. J., and Sutow, W. W. Vincristine sulfate in the treatment of neuroblastoma in children. Am. J. Dis. Child., 111: 75 (1966).

46. Zager, R. F., Frisby, S. A., and Oliverio, V. T.: The effects of antibiotics and cancer chemotherapeutic agents on the cellular transport and antitumour activity of methotrexate in L1210 murine leukemia. Cancer Res., 33: 1670 (1973).

47. The authors are pleased to acknowledge the technical expertise of Lorrainne Dennis in carrying out these studies. We are grateful to Dr. J. Kemshead at the I.C.R.F. for kindly providing the CHP100 cells which were obtained from Dr. H. R. Schlesinger, The Children's Hospital, Philadelphia, PA and to Drs. J. Cowell and Ellen Solomon for advice on chromosomal analyses. We thank Professor J. S. Malpas for his interest in our studies and for making the experimental agent $4^{\prime}$-(9-acridimylamino)methanesulfon-m-anisidide (NSC 249992) available to us for this work via a gift from Dr. J. H. Wier, WarnerLambert Co.. Morris Plains, NJ. The many helpful discussions with Dr. J. Pritchard. The Children's Hospital, Great Ormond Street, London. England have been much appreciated, and we thank him for providing the up-to-date clinical information on which our correlations have been based. Our thanks go also to Eileen Simmons for her secretarial assistance, to Audrey Symmons for the artwork, and to the staff of the I.C.R.F. Photographic Department for help in the final preparation of this manuscript for publication.

48. Requests for reprints should be addressed to: Dr. Bridget T. Hill, Laboratory of Cellular Chemotherapy, Imperial Cancer Research Fund, Lincoln`s Inn Fields. London EC2A 3PX. United Kingdom.

49. Received for publication October 27, 1980.

50. Accepted for publication December 18, 1980. 